\title{
Thermobacillus composti sp. nov., a moderately thermophilic bacterium isolated from a composting reactor
}

\author{
Keiko Watanabe, ${ }^{1}$ Norio Nagao, ${ }^{2}$ Shuich Yamamoto, ${ }^{1}$ \\ Tatsuki Toda ${ }^{1}$ and Norio Kurosawa ${ }^{1}$ \\ ${ }^{1}$ Department of Environmental Engineering for Symbiosis, Faculty of Engineering, \\ Soka University, 1-236 Tangi-cho, Hachioji, Tokyo 192-8577, Japan \\ ${ }^{2}$ SEAWELL Co. Ltd, 8-12-6 Ginza, Chuo-ku, Tokyo 104-0061, Japan
}

Correspondence

Norio Kurosawa

kurosawa@t.soka.ac.jp

\begin{abstract}
A Gram-negative, rod-shaped, spore-forming and moderately thermophilic bacterium, strain $\mathrm{KWC} 4^{\top}$, was isolated from a composting reactor. Cells of strain $\mathrm{KWC} 4^{\top}$ were $2.0-5.0 \mu \mathrm{m}$ long and $0.5-0.7 \mu \mathrm{m}$ in diameter. Strain $\mathrm{KWC} 4^{\top}$ grew aerobically at $32-61^{\circ} \mathrm{C}$, with optimal growth occurring at $50^{\circ} \mathrm{C}$. It grew at $\mathrm{pH} 5.6-10.1$, with optimal growth at around $\mathrm{pH} 9.0$. The optimum $\mathrm{NaCl}$ concentration for growth was almost $0 \%(\mathrm{w} / \mathrm{v})$, but strain $\mathrm{KWC} 4^{\top}$ was moderately halotolerant and was able to grow at $\mathrm{NaCl}$ concentrations up to $4.4 \%(\mathrm{w} / \mathrm{v})$. The DNA G+C content of strain $\mathrm{KWC} 4^{\top}$ was 60.0 mol\%. The major fatty acids were iso-16:0 (39.0\%) and anteiso-15: 0 (33.3\%). Based on 16S rRNA gene sequence similarity data, strain KWC4 ${ }^{\top}$ belonged to the genus Thermobacillus and was related to Thermobacillus xylanilyticus. However, strain $\mathrm{KWC} 4^{\top}$ had a 38 bp insertion sequence located near the $3^{\prime}$ end of its $16 \mathrm{~S}$ rRNA gene that was not present in T. xylanilyticus. The 16S rRNA gene sequence similarity value between strain $\mathrm{KWC} 4^{\top}$ and T. xylanilyticus was $95.7 \%$. The DNA-DNA hybridization value between strain $\mathrm{KWC} 4^{\top}$ and T. xylanilyticus strain $\mathrm{XE}^{\top}$ was $66 \%$. On the basis of phenotypic and genotypic evidence, strain $\mathrm{KWC} 4^{\top}\left(=\mathrm{DSM} 18247^{\top}=\mathrm{JCM} 13945^{\top}\right)$ is the type strain of a novel species, for which the name Thermobacillus composti sp. nov. is proposed.
\end{abstract}

In recent years, the importance of the use of biotechnology for organic solid waste treatment has increased exponentially since biological processes appear to be cost-effective and have a less negative environmental impact than other treatment processes. Fed-batch composting (FBC) is an efficient way to treat organic waste without generating harmful compounds such as dioxins that are produced by incineration. In composting processes, thermophilic and mesophilic micro-organisms have important functions in terms of nutrient recycling and decomposition of complex organic substrates. Several culture-dependent microbial studies involved in the composting process have been reported and various species of bacteria, e.g. members of families such as the Bacillaceae, Clostridiaceae, Flavobacteri-

Abbreviations: FBC, fed-batch composting; SEM, scanning electron microscope.

The GenBank/EMBL/DDBJ accession number for the 16S rRNA gene sequence of strain $\mathrm{KWC}^{\top}{ }^{\top}$ is $\mathrm{AB} 254031$.

A table showing the cellular fatty acid contents of strain $\mathrm{KWC}^{\top}, T$. xylanilyticus and some representatives of the genus Paenibacillus and a phylogenetic tree based on 16S rRNA gene sequences of strain KWC4 ${ }^{\top}$ and related species constructed using the maximum-likelihood method are available as supplementary material with the online version of this paper. aceae, Neisseriaceae, Nocardiopsaceae and Staphylococcaceae, have been isolated. Moreover, many viable but nonculturable micro-organisms have also been detected by culture-independent methods from the contents of composting reactors (Dees \& Ghiorse, 2001; Haruta et al., 2002; Narihiro et al., 2004). Therefore, composting reactors may contain many novel species of bacteria. Recently, some novel species have been isolated from FBC reactors. For example, Paenibacillus motobuensis was derived from a composting machine utilizing soil (Iida et al., 2005) and Cerasibacillus quisquiliarum was isolated from a semi-continuous decomposing system for kitchen refuse (Nakamura et al., 2004).

During a screen for novel species from an FBC reactor, a moderately thermophilic bacterium, strain $\mathrm{KWC}^{\mathrm{T}}$, was isolated. 16S rRNA gene sequence analysis indicated that strain $\mathrm{KWC4}^{\mathrm{T}}$ represented a novel species of the genus Thermobacillus. The genus Thermobacillus was proposed by Touzel et al. (2000) to contain Gram-negative, sporeforming, aerobic, non-motile, rod-shaped thermophiles. To date, only a single species, Thermobacillus xylanilyticus, has been described (Touzel et al., 2000). This paper reports the isolation, characterization and taxonomic classification of strain KWC4 $4^{\mathrm{T}}$. 
An FBC reactor for household use, the 'Namagomi-eater' (TK401-T, Matsushita Electric Works), was used for the composting reaction. The working volume of the reactor was $15 \mathrm{l}$ and the temperature was usually maintained above $40^{\circ} \mathrm{C}$ and reached about $60^{\circ} \mathrm{C}$ during active degradation of organic matter. The biomass carrier comprised $51(1.2 \mathrm{~kg}$ wet wt) wood chips (about $0.5-2.0 \mathrm{~mm}$ ). The artificial organic waste [500 g dog food containing $80 \%(\mathrm{w} / \mathrm{w})$ water] was loaded daily into the reactor. The contents were gently mixed twice per minute by automated paddles. The sample from which the micro-organism was isolated was taken from the optimal conditioned reactor in which the rate of decomposition of organic matter was about $17 \mathrm{gl}^{-1}$ day $^{-1}$. The temperature and $\mathrm{pH}$ of the sample were $47^{\circ} \mathrm{C}$ and 8.6, respectively. The diluted sample was plated onto modified Brock's basal salts (MBS) (Kurosawa et al., 1998) supplemented with $0.2 \%(\mathrm{w} / \mathrm{v})$ yeast extract, $\mathrm{pH} 7.5$, solidified by $0.7 \%(\mathrm{w} / \mathrm{v})$ Gelrite and incubated at $50{ }^{\circ} \mathrm{C}$ for $24 \mathrm{~h}$. Colonies were isolated and purified by repeating single-colony isolation. One of the isolates, strain $\mathrm{KWC}^{\mathrm{T}}$, was assumed to be a member of a novel species by preliminary analysis of $16 \mathrm{~S}$ rRNA gene sequences.

To characterize strain $\mathrm{KWC}^{\mathrm{T}}$ phenotypically, standard tests were performed, including Gram staining, cell morphology, motility, catalase and oxidase production and acid or gas production from glucose (Barrow \& Feltham, 1993). Cell morphology and motility were examined by using a phasecontrast microscope (Axioskop 40; Carl Zeiss) and a scanning electron microscope (SEM) (JSM-5600LV; JEOL). For SEM observation of the cells, samples of exponential-phase cultures were applied onto carbon-coated SEMporeB filters (JEOL Datum) and then washed with distilled water. After freeze-drying, samples were metal-shadowed with platinum and examined in high-vacuum mode at $10 \mathrm{kV}$.

The potential for growth at various initial $\mathrm{pH}$ values was determined using MBS supplemented with $0.5 \%(\mathrm{v} / \mathrm{v})$ yeast extract at $50^{\circ} \mathrm{C}$. The growth temperature and optimal $\mathrm{NaCl}$ concentrations were determined using the same medium at $\mathrm{pH}$ 9.0. Anaerobic growth was examined by using an AnaeroPack jar (Mitsubishi Gas Chemical). Enzymic activities were analysed by the API ZYM kit (bioMérieux) according to the manufacturer's instructions except for the incubation temperature, which was adjusted to $50{ }^{\circ} \mathrm{C}$. Utilization of D-cellobiose, dextrin, erythritol, D-fructose, D-galactose, glucose, lactose, maltose, D-mannose, melibiose, D-sorbitol, sucrose, trehalose and D-xylose were tested. Hydrolysis of casein, starch and xylan were also examined. Cells for fatty acid analysis were grown on MBS plates at $50{ }^{\circ} \mathrm{C}$ for $24 \mathrm{~h}$. Fatty acid methyl esters were prepared and identified following the Sherlock Microbial Identification system instructions (MIDI). The resultant esters were separated using a GC (HP6890; Hewlett Packard). The G + C content of DNA of strain $\mathrm{KWC4}^{\mathrm{T}}$ was determined by HPLC (LC-10; Shimadzu) using genomic DNA digested with nuclease P1 (DNA-GC kit; SEIKAGAKU) (Katayama-Fujimura et al., 1984). DNA-DNA hybridization experiments were carried out three times independently as described by Ezaki et al. (1989). Thermobacillus xylanilyticus strain $\mathrm{XE}^{\mathrm{T}}$ was kindly provided by J. P. Touzel and was used for comparison. Isoprenoid quinones were extracted with chloroform/ methanol $(2: 1, \mathrm{v} / \mathrm{v})$ and were analysed by using fast-atom bombardment-MS (EI/FAB mate BU25; JEOL) with diethanolamine as a matrix for the negative MS.

The 16S rRNA gene of strain KWC4 ${ }^{\mathrm{T}}$ was amplified by PCR using the bacterial universal primers B27F (forward; 5' AGAGTTTGATCMTGGCTCAG, positions 8-27 based on Escherichia coli numbering) and U1492RM (reverse; 5'GGYTACCTTGTTACGACTT, positions 1510-1492 based on E. coli numbering). The following thermal cycle was used for 25 cycles: $95^{\circ} \mathrm{C}$ for $30 \mathrm{~s}, 60^{\circ} \mathrm{C}$ for $30 \mathrm{~s}$ and $72^{\circ} \mathrm{C}$ for $1.5 \mathrm{~min}$. DNA sequencing was carried out by the dideoxynucleotide chain-termination method with Texas-redlabelled primers using the ThermoSequenase Primer Cycle Sequencing kit (GE Healthcare Biosciences) and an automated DNA sequencer (SQ5500E; Hitachi). The 16S rRNA gene sequence of strain $\mathrm{KWC}^{\mathrm{T}}$ was compared with available 16S rRNA gene sequences in the NCBI nucleotide sequence database using BLAST (http://www.ncbi.nlm.nih. gov/blast/) (Altschul et al., 1990). Twenty-nine 16S rRNA gene sequences of related species were aligned using CLUSTAL W (Thompson et al., 1994) and all sites with gaps in any sequences and regions of the PCR primers were removed from the alignment. Phylogenetic trees were reconstructed using the neighbour-joining (Saitou \& Nei, 1987) and maximum-likelihood (Felsenstein, 1981) methods and algorithms were integrated in the PHYLIP package (Felsenstein, 1993). The stability of relationships was assessed by performing bootstrap analyses of the neighbour-joining data based on 1000 resamplings.

Colonies of strain $\mathrm{KWC}^{\mathrm{T}}$ on MBS plates were $0.5-1.0 \mathrm{~mm}$ in diameter, light-cream in colour, round and half-opaque, but sometimes exhibited an irregular, flat morphology and had rather undulate margins. Cells of strain $\mathrm{KWC}^{\mathrm{T}}$ were 2.0-5.0 $\mu \mathrm{m}$ long and $0.5-0.7 \mu \mathrm{m}$ in diameter (Fig. 1). Endospores were formed at the middle of the cell (data not shown). Cells of strain $\mathrm{KWC}^{\mathrm{T}}$ were aerobic, Gramnegative, spore-forming, occurred singly and occasionally in pairs or chains, and were non-motile and catalase- and oxidase-positive. Strain $\mathrm{KWC}^{\mathrm{T}}$ utilized D-cellobiose, Dfructose, D-galactose, D-xylose, D-mannose, lactose, melibiose, starch, trehalose and xylan; T. xylanilyticus, the type species of the genus, also utilized these substrates. Strain $\mathrm{KWC4}^{\mathrm{T}}$ also utilized D-glucose, maltose, sucrose and dextrin. Alkaline phosphatase, esterase, leucine arylamidase, trypsin, acid phosphatase, naphthol-AS-BI-phosphohydrolase, $\alpha$-galactosidase, $\beta$-galactosidase, $\beta$-glucuronidase, $\alpha$ glucosidase, $\beta$-glucosidase, $N$-acetyl- $\beta$-glucosaminidase and $\alpha$-fucosidase activities were detected; no lipase, valine arylamidase, chymotrypsin or $\alpha$-mannosidase activities were found. Acid or gas production from glucose was negative.

Strain $\mathrm{KWC}^{\mathrm{T}}$ grew at $32-61{ }^{\circ} \mathrm{C}$ and $\mathrm{pH}$ 5.6-10.1, with optimal growth occurring at $50^{\circ} \mathrm{C}$ and around $\mathrm{pH}$ 9.0. The 

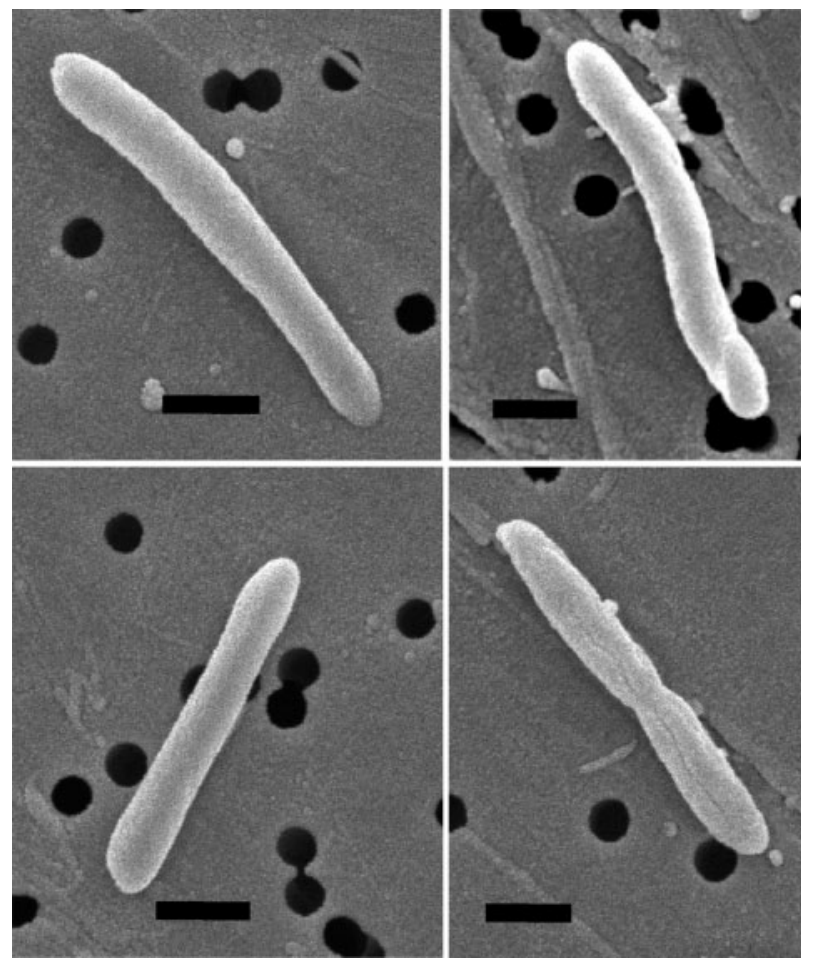

Fig. 1. SEM images of cells of strain $\mathrm{KWC}^{\top}$. Bars, $1 \mu \mathrm{m}$.

optimum $\mathrm{NaCl}$ concentration for growth of strain $\mathrm{KWC} 4^{\mathrm{T}}$ was almost $0 \%(\mathrm{w} / \mathrm{v})$, but it was moderately halotolerant and was able to grow at $\mathrm{NaCl}$ concentrations up to $4.4 \%$ $(\mathrm{w} / \mathrm{v})$. The DNA G+C content of strain $\mathrm{KWC4}^{\mathrm{T}}$ was $60.0 \mathrm{~mol} \%$. The optimal $\mathrm{pH}$, maximum $\mathrm{NaCl}$ concentration for growth and the DNA $\mathrm{G}+\mathrm{C}$ content of strain $\mathrm{KWC}^{\mathrm{T}}$ were slightly higher than those of T. xylanilyticus (Table 1). The major fatty acids of strain $\mathrm{KWC}^{\mathrm{T}}$ were iso-16:0 (39.0\%) and anteiso-15:0 (33.3\%). This fatty acid composition also distinguished strain $\mathrm{KWC}^{\mathrm{T}}$ from $T$. xylanilyticus and species of the genus Paenibacillus (see Supplementary Table S1 available in IJSEM Online). The major isoprenoid quinone of strain $\mathrm{KWC} 4^{\mathrm{T}}$ was MK-6 $\left(\mathrm{H}_{8}\right)$, in contrast to T. xylanilyticus, which had MK-7 as the major isoprenoid quinone (Touzel et al., 2000).

The almost full-length $16 \mathrm{~S}$ rRNA gene sequence (1528 bp) of strain $\mathrm{KWC}^{\mathrm{T}}$ was determined. Phylogenetic analysis based on 16S rRNA gene sequences showed that strain $\mathrm{KWC4}^{\mathrm{T}}$ was most closely related to T. xylanilyticus; their $16 \mathrm{~S}$ rRNA gene sequences showed $95.7 \%$ similarity. The neighbour-joining tree showed that $\mathrm{KWC4}^{\mathrm{T}}$ and $T$. xylanilyticus form a monophyletic cluster with a bootstrap value of $100 \%$ (Fig. 2). This cluster was also distinct from other genera, i.e. Cohnella and Paenibacillus, in the maximum-likelihood tree (see Supplementary Fig. S1 available in IJSEM Online). Interestingly, strain $\mathrm{KWC}^{\mathrm{T}}$ has a $38 \mathrm{bp}$ insertion sequence near the $3^{\prime}$ end of the $16 \mathrm{~S}$ rRNA gene compared with the sequence of T. xylanilyticus. The 16S rRNA gene sequences of strain $\mathrm{KWC}^{\mathrm{T}}$ and $T$. xylanilyticus showed a similarity value of $98.3 \%$ when the insertion sequence was removed from the alignment. This unusual insertion sequence was also found in the 16S rRNA gene sequence of Paenibacillus nematophilus strain NEM3 (Enright et al., 2003). In addition, when compared with other bacteria, strain $\mathrm{KWC}^{\mathrm{T}}$ and T. xylanilyticus have a $36 \mathrm{bp}$ insertion sequence located near the $5^{\prime}$ end of the $16 \mathrm{~S}$ rRNA gene. This insertion sequence may be unique for the genus Thermobacillus. DNA-DNA hybridization experiments were also performed between strain $\mathrm{KWC}^{\mathrm{T}}$ and T. xylanilyticus strain $\mathrm{XE}^{\mathrm{T}}$. The DNA-DNA reassociation value was $66 \%$ (SD $5.4 \%$ ). This value is relatively high for members of different species, but phenotypic signatures suggest that strain $\mathrm{KWC} 4^{\mathrm{T}}$ should be defined independently from T. xylanilyticus. Based on phylogenetic evidence, together with phenotypic and chemotaxonomic data, strain $\mathrm{KWC4}^{\mathrm{T}}$ is proposed as a representative of a novel species of the genus Thermobacillus, Thermobacillus compost $i$ sp. nov.

Table 1. Comparison of phenotypic characteristics of strain $\mathrm{KWC} 4^{\top}$ and T. xylanilyticus

\begin{tabular}{|lcc|}
\hline Characteristic & Strain $\mathbf{K W C 4}^{\mathbf{T}}$ & T. xylanilyticus $\mathbf{X E}^{\mathbf{T}_{*}}$ \\
\hline Temperature range for growth $\left({ }^{\circ} \mathrm{C}\right)$ & $32-61$ & $\mathrm{Up}$ to 63 \\
Optimum temperature for growth $\left({ }^{\circ} \mathrm{C}\right)$ & 50 & 55 \\
pH range & $5.6-10.1$ & $6.5-8.5$ \\
Optimum $\mathrm{pH}$ & 9.0 & 7.8 \\
NaCl range $(\%, \mathrm{w} / \mathrm{v})$ & $0-4.4$ & $0-3.0$ \\
DNA G+C content $(\mathrm{mol} \%)$ & 60.0 & 57.5 \\
Major fatty acid $(\%, \mathrm{w} / \mathrm{w})$ & iso-16:0 $(39.0)$, & iso-16:0 $(48.0)$, \\
& anteiso-15:0 (33.3) & $16: 0(21.4)$ \\
Major isoprenoid quinone & MK-6 & MK-7 \\
\hline
\end{tabular}

${ }^{\star}$ Touzel et al. (2000). 


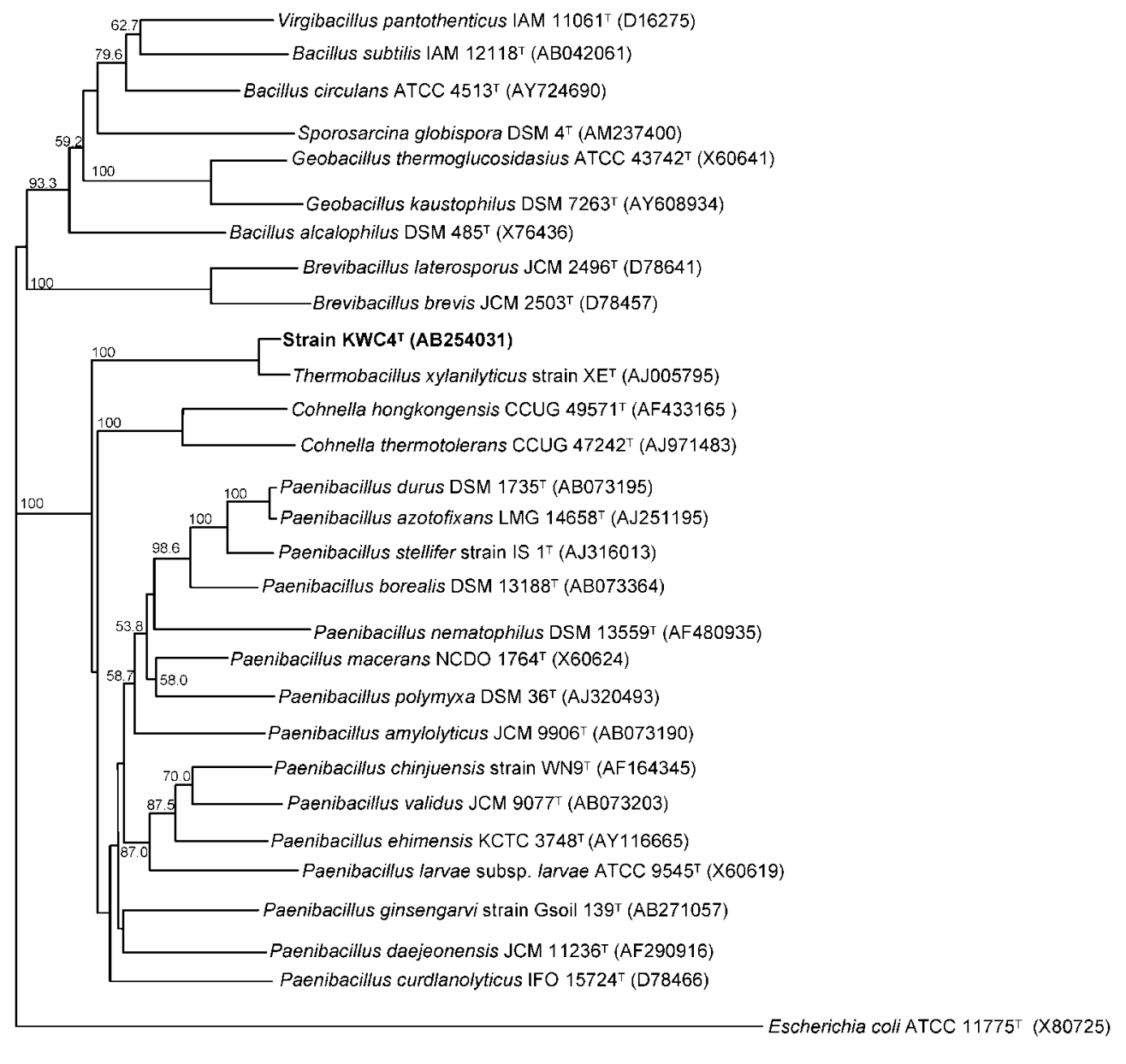

0.1

Fig. 2. Phylogenetic tree based on $16 \mathrm{~S}$ rRNA gene sequences of strain $\mathrm{KWC} 4^{\top}$ and related species constructed by the neighbour-joining method with Escherichia coli as the outgroup species. GenBank accession numbers of the sequences used in this study are shown in parentheses. The numbers at each node are bootstrap values performed with 1000 replicates. Bootstrap values less than $50 \%$ are not shown. Bar, $10 \%$ nucleotide substitution.

Description of Thermobacillus composti sp. nov.

Thermobacillus composti (com.pos'ti. N.L. gen. neut. n. composti of/from compost).

Cells are non-motile, spore-forming rods (approx. 2.0$5.0 \mu \mathrm{m}$ long). Aerobic and Gram-negative. Catalase- and oxidase-positive. Colonies are light-cream in colour, round and half-opaque, but sometimes exhibit an irregular, flat morphology. Grows at $32-61{ }^{\circ} \mathrm{C}$ and $\mathrm{pH}$ 5.6-10.1, with optimal growth at $50^{\circ} \mathrm{C}$ and around $\mathrm{pH}$ 9.0. Optimal $\mathrm{NaCl}$ concentration is almost $0 \%$, but is able to grow at $\mathrm{NaCl}$ concentrations up to $4.4 \%(\mathrm{w} / \mathrm{v})$. The following compounds are utilized: D-cellobiose, dextrin, D-fructose, Dgalactose, D-glucose, lactose, maltose, D-mannose, melibiose, starch, sucrose, trehalose, D-xylose and xylan. Erythritol, sorbitol, and casein are not utilized. The major fatty acids are iso-16:0 (39.0\%) and anteiso-15:0 (33.3\%).
The major isoprenoid quinone is $\mathrm{MK}-6\left(\mathrm{H}_{8}\right)$. DNA-DNA relatedness between strain $\mathrm{KWC}^{\mathrm{T}}$ and Thermobacillus xylanilyticus strain $\mathrm{XE}^{\mathrm{T}}$ is $66 \%$. The DNA G $+\mathrm{C}$ content of the type strain is $60.0 \mathrm{~mol} \%$.

The type strain, $\mathrm{KWC}^{\mathrm{T}}\left(=\mathrm{DSM} 18247^{\mathrm{T}}=\mathrm{JCM} 13945^{\mathrm{T}}\right)$, was isolated from a fed-batch composting reactor.

\section{Acknowledgements}

We thank Dr Jean P. Touzel for providing a culture of Thermobacillus xylanilyticus and Dr Hans G. Trüper for advice on nomenclatural etymology. We also thank Shinichiro Osa for technical assistance, Takeo Suzuki for assistance with electron microscopy and Victor S. Kuwahara for correcting the English. This work was supported by 'University-Industry Joint Research' Project for Private Universities: matching fund subsidy from MEXT (Ministry of Education, Culture, Sports, Science and Technology), 2004-2008. 


\section{References}

Altschul, S. F., Gish, W., Miller, W., Myers, E. W. \& Lipman, D. J. (1990). Basic local alignment search tool. J Mol Biol 215, 403-410.

Barrow, G. I. \& Feltham, R. K. A. (1993). Cowan and Steel's Manual for the Identification of Medical Bacteria, 3rd edn. Cambridge: Cambridge University Press.

Dees, P. M. \& Ghiorse, W. C. (2001). Microbial diversity in hot synthetic compost as revealed by PCR-amplified rRNA sequences from cultivated isolates and extracted DNA. FEMS Microbiol Ecol 35, 207-216.

Enright, M. R., McInerney, J. O. \& Griffin, C. T. (2003). Characterization of endospore-forming bacteria associated with entomopathogenic nematodes, Heterorhabditis spp., and description of Paenibacillus nematophilus sp. nov. Int J Syst Evol Microbiol 53, 435-441.

Ezaki, T., Hashimoto, Y. \& Yabuuchi, E. (1989). Fluorometric deoxyribonucleic acid-deoxyribonucleic acid hybridization in microdilution wells as an alternative to membrane filter hybridization in which radioisotopes are used to determine genetic relatedness among bacterial strains. Int J Syst Bacteriol 39, 224-229.

Felsenstein, J. (1981). Evolutionary trees from DNA sequences: a maximum likelihood approach. J Mol Evol 17, 368-376.

Felsenstein, J. (1993). PHYLIP (phylogeny inference package), version 3.5c. Department of Genome Sciences, University of Washington, Seattle, USA.

Haruta, S., Kondo, M., Nakamura, K., Aiba, H., Ueno, S., Ishii, M. \& Igarashi, Y. (2002). Microbial community changes during organic solid waste treatment analyzed by double gradient-denaturing gradient gel electrophoresis and fluorescence in situ hybridization. Appl Microbiol Biotechnol 60, 224-231. lida, K., Ueda, Y., Kawamura, Y., Ezaki, T., Takade, A., Yoshida, S. \& Amako, K. (2005). Paenibacillus motobuensis sp. nov., isolated from a composting machine utilizing soil from Motobu-town, Okinawa, Japan. Int J Syst Evol Microbiol 55, 1811-1816.

Katayama-Fujimura, Y., Komatsu, Y., Kuraishi, H. \& Kaneko, T. (1984). Estimation of DNA base composition by high performance liquid chromatography of its nuclease P1 hydrolysate. Agric Biol Chem 48, 3169-3172.

Kurosawa, N., Itoh, Y. H., Iwai, T., Sugai, A., Uda, I., Kimura, N., Horiuchi, T. \& Itoh, T. (1998). Sulfurisphaera ohwakuensis gen. nov., sp. nov., a novel extremely thermophilic acidophile of the order Sulfolobales. Int J Syst Bacteriol 48, 451-456.

Nakamura, K., Haruta, S., Ueno, S., Ishii, M., Yokota, A. \& Igarashi, Y. (2004). Cerasibacillus quisquiliarum gen. nov., sp. nov., isolated from a semi-continuous decomposing system of kitchen refuse. Int J Syst Evol Microbiol 54, 1063-1069.

Narihiro, T., Abe, T., Yamanaka, Y. \& Hiraishi, A. (2004). Microbial population dynamics during fed-batch operation of commercially available garbage composters. Appl Microbiol Biotechnol 65, 488-495.

Saitou, N. \& Nei, M. (1987). The neighbor-joining method: a new method for reconstructing phylogenetic trees. Mol Biol Evol 4, 406-425.

Thompson, J. D., Higgins, D. G. \& Gibson, T. J. (1994). CLUSTAL_W: improving the sensitivity of progressive multiple sequence alignment through sequence weighting, position-specific gap penalties and weight matrix choice. Nucleic Acids Res 22, 4673-4680.

Touzel, J. P., O’Donohue, M., Debeire, P., Samain, E. \& Breton, C. (2000). Thermobacillus xylanilyticus gen. nov., sp. nov., a new aerobic thermophilic xylan-degrading bacterium isolated from farm soil. Int J Syst Evol Microbiol 50, 315-320. 